\title{
Peer to Peer Lending Platform can Influence investors to help Capital for Small Business Enterprise
}

\author{
A Umar, A H Sasongko, Sugiharto, Y Christanti, A Bawono, Hariyatno \\ Management Department, Universitas Bina Nusantara, Jakarta, Indonesia \\ abdullah.umar@binus.ac.id
}

\begin{abstract}
Peer to peer lending as a platform that can bring together investors and recipients of funds (SMEs). Because all this time, prospective investors do not have confidence in how SME owners can use the capital provided correctly. Likewise, with SMEs, it is often difficult to get capital as part of business development. With peer to peer lending, there are companies that mediate between the two parties. In addition to economic aspects, the company has a social aspect, which helps improve the welfare of SMEs by providing various services such as training. In this context, data was collected from potential investors, investors, peer to peer lending companies and SMEs that received the funding. This study uses a qualitative method. Where the author wants to find out how far this peer to peer lending platform can help investors, so they want to participate in developing SMEs and the benefits received by SMEs from peer to peer lending.
\end{abstract}

Keywords: SMEs, Investors, Peer To Peer Lending Companies

\section{INTRODUCTION}

The growth of SMEs in Indonesia is quite large. Almost in every region has started popping up various small businesses that began to grow. Moreover, the government gives full support to the establishment of this small business. Because with the support of this small business, the Indonesian economy will remain well preserved. This is evident when Indonesia experienced an economic crisis in 1997. The crisis that hit Indonesia in 1997 started with the crisis of the rupiah against the US dollar and the monetary crisis that impacted the economy of Indonesia that is economic recession. With these conditions, it takes a strong economic structure to sustain the economy of a country [1]. The crisis affected the number of large companies that collapsed. However, small businesses were able to stand and sustain the economy in Indonesia at the time. There are several reasons why this small business can stand firmly when the economic crisis hit Indonesia, namely: (1) This small enterprise produces a variety of products that people really need, such as ingredients of consumption; (2) Utilizing the various resources that exist around the place of business, such as human resources and raw materials; (3)Utilizing existing capital, i.e. own capital or if it requires a large capital will then make the process of borrowing with large debts that are not large.

For A SME to become big often get constraints and eventually the SMEs are acquired by larger companies so they can compete in the international market [2]. To start a new business, various considerations and good planning are required, including plans before and after running a business, otherwise it should have a plan for a certain period of time such as plans for the next two years. Some things to consider in building a business is a matter of finance, 
sales and marketing [3]. In running the business, small businesses often face obstacles in the development of business so that it can threaten the survival of the company. One of the factors that affect the success of this business is the decision-making process and business strategy that will be executed [4].

Small business owners who do not have the ability in the field of managerial either in the field of marketing, sales, finance and ability in business strategy. They think that in running a small business does not require good managerial skills, simply provide goods and sales [5]. There are several factors that cause less development of a small business, namely: (1) Lack of capital to run a business; (2) The high level of competition especially with similar business; (3) Lack of knowledge about management; (4) Difficulty obtaining raw materials; (5) Lack of understanding of financial problems at the company. Of all the problems that are often a threat to SMEs business is about capital. SME owners always assume that capital is the key in establishing a business. Thus, this capital becomes a major problem for SMEs in developing business.

Of course, with these provisions, facilitate SMEs to make borrowing so that business capital will be more increased. However, many requirements are the cause until the owners of SMEs difficult to make these loans. And the addition of this capital, just thought of when the business is already running. The most often done to increase capital is to make loans to the bank. There are several alternative loans other than to the bank, namely:(1) Borrow money to family or close friends;(2) Sell less productive property;(3) Borrow money without bail, (4) Borrow money in a pawnshop;(5) Borrow money in credit cooperatives;(6) Borrow money at a traveling bank(7). Borrow money in loan sharks [6].

\section{METHOD}

The method used in this study using qualitative methods. Where this research is focused on the relationship between investors as an investment fund and Small and Medium Enterprises as recipients of investment funds. During this time there are some people who want to help this small business, but there are some problems felt by the investors, among others: The invested capital is not large and there is a fear factor if the capital provided as part of the investment does not return or the company is experiencing bankruptcy.

Data collection in this study by using three methods, namely:

\subsection{Interview}

The data used in this study was collected through interviews. Interviews are conducted face to face to see the expression given when answering questions given. There are three parts that become object of question, that is:

Table 1. Participants in the Research

\begin{tabular}{ll}
\hline \multicolumn{1}{c}{ Type } & \multicolumn{1}{c}{ Object } \\
\hline Investor & Community \\
Small and Medium Entreprises & Business Owner \\
Investree & Investree Company \\
\hline
\end{tabular}

By asking questions to these three objects, it will be known what is desired or that is feared by all parties, especially investors who will invest money as capital for small and medium enterprises. One way to get information directly is by using the method of interview, where 
the interview will be directly on the subject of existing problems so that it can be immediately taken the conclusion of the incident felt by the perpetrator [7]. In the interview will provide a clear picture of the facts that occur from resource persons to the object of research, so that the direction of the interview will be known appropriately [8].

\subsection{Observation}

Observation is one of the research methods used, namely direct observation, especially on small and medium business. In qualitative research there are several forms of observation used, namely observation in the form of participation, structured observation and unstructured observation [9]. In this research using unstructured observation method, that is observation done without observation guide. Researchers directly observe the business that is running. The oversight is done directly on the ongoing business. Whether it's seen from location to when serving the consumer.

For this observation, researchers directly observed the activities in three objects, namely: (a) Peer to peer lending companies, how the company is a bridge between investors and SMEs; (b) Investors, those who want to channel their funds to be channeled to SMEs with assistance from peer to peer lending; (c) UKM, as a party that is given assistance by investors through intermediaries from peer to peer lending.

From the existing observations, it can be seen the process of money circulation, from product offerings to prospective investors in this case which SMEs will be funded, to the use of funds by SMEs can be accounted for.

\subsection{Library Study}

Library study is used in this research, where this method is useful to collect all information relating to investors and SMEs as well as rules governing all that. This case study is taken from a book or journal.

\subsection{Data Analysis}

The process of collecting data is done on the object of research, after completion of the data collection process. Then performed data analysis. If during validation there are some data that have not been fulfilled, then additional interview is required. Additional interviews can be done on the same person or with different people but have the required object standard. That data analysis can be done by using four stages, namely research using theoretical proposition as data analysis, description development, then using quantitative data and using qualitative data that will combine all information to be processed into expected data.

In this study, after the interviews and observations made to SMEs who receive and have not received the investment, the Company is a mediator between SMEs and investors and to investors. then the data is analyzed. The results of the analysis will then be adjusted to the review literature.

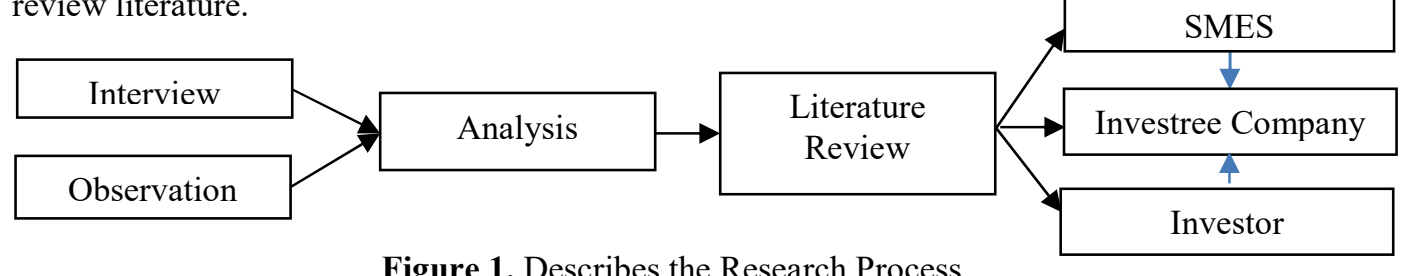

Figure 1. Describes the Research Process 


\section{RESULT AND DISCUSSION}

\subsection{Micro, Small and Medium Enterprises}

Small and medium enterprises is one of the many fields that contribute positively to the development and growth of the economy in Indonesia. This can be seen from the absorptive power of a very large labor source. In addition, small and medium enterprises can be large due to support from surrounding communities who share the positive impact with the existence of small and medium enterprises. However, this existing SMEs cannot grow rapidly, because it has various weaknesses, among others, ignorance of the owners in marketing and promoting products to the public [9]. Small and medium enterprises is a term that refers to the type of small business that has a net worth of at most IDR. 200,000,000 excluding land and building of business premises. Understanding Micro, Small and Medium Enterprises described in the Law of Micro, Small, Medium Enterprises (MSMEs) no. 20 of 2008 are as follows: (1) MicroEnterprise is productive business owned by individual and / or individual business entity fulfilling the criteria of Micro Enterprises as regulated in this Law; (2) Small-scale business is a stand-alone productive economic enterprise, conducted by an individual or a business entity that is not a subsidiary or not a branch of a company owned, controlled, or becomes part directly or indirectly from a medium-sized or large-scale business that meets criteria for smallscale enterprises as referred to in this Law; (3) Medium-sized Business is a stand-alone productive economic enterprise, carried out by an individual or business entity that is not a subsidiary or branch of a company owned, controlled, or becomes part directly or indirectly with a Small Business or a large business with the amount of wealth net or annual sales proceeds as provided in this Law.

Micro, Small and Medium Enterprises is one that can contribute directly to the growth of Indonesian economy. Because UMKM can absorb a large enough workforce and its scope is around the surrounding community. However, SMEs in Indonesia still keep a myriad of problems, including how to do marketing so that can be known by the public. Approximately $88.8-99.9 \%$ of the form of business in Indonesia is in the form of MSMEs with employment of $51.7-97.2 \%$. Therefore, the development and resilience of MSMEs should take precedence. Where the government through Law no. 5 Year 1995, the member restriction on SMEs that is for small business is business that: (1) Have 200 million net assets, excluding Land and Building of business place; (2) Annual sales proceeds (turnover) at most 1 Billion; (3) Owned by Indonesian citizens; (4) Stand alone, not a branch office or a subsidiary.

\subsection{Crowd Funding}

One of the obstacles for beginning entrepreneurs or SMEs in Indonesia is the problem of capital, the provision of raw materials and how to market the products produced. Of the three existing problems, the most experienced is the problem of capital. Because of this capital process on SMEs will continue. Such as ease in providing raw materials or doing the marketing process such as advertising. To grow the business, these small entrepreneurs have various ways to obtain capital loans, etc. from Banks, Cooperatives, as well as from personal sources. However, in the context of obtaining loans cannot be imagined, because there are several things to note, including loans, procedures for obtaining capital, as well as any length of time required [10].

One way for SMEs to get capital is to get funding from investors. An investor is a person who invests or invests in a company whether it is a large individual or a large-scale company. 
This investment can be done by providing capital part of the investment. This investment aims to help the company expand its business. However, investors personally have their own fears to provide capital to SMEs, because there is a concern that SMEs cannot return the capital given. So, it takes a method that helps the investors to be able to provide capital assistance to the SMEs. The method is called crowdfunding. Financing a project or a business does not require large amounts of financing at the same time, but the financing can be done by collecting some funds from several investors so that collected into one large fund or can be called crowdfunding [11]. The method of raising funds or commonly referred to as crowdfunding can be used by all societies in general by utilizing the internet as a medium for collecting donations in the form of money or other benefits, where donations in the form of finances are often without the expected rewards that can support an objective of the funding [12]. There are four types of crowdfunding: (1) Equity-based crowdfunding; (2) Lending-based crowdfunding (Investment Crowdfunding); (3) Reward-based crowdfunding; (4) Donation-based crowdfunding [13].

In Indonesia the benefit of crowdfunding as a fund provider is still relatively new. And began to stand various companies that use crowdfunding as its business strategy. Popular enough is crowdfunding using debt financing or peer to peer loans. Where small companies or SMEs borrow to investors via online platform and return the loan with interest. One of the most popular financing systems today is the peer to peer platform, which uses a media platform to manage the funds provided by investors to help capital needs from SMEs, this relationship does not stop when SMEs have capital. But investors remain connected to the platform to continue to see in detail the performance of the good SMEs in the form of work plans, to financial reports [14]. In Indonesia alone peer to peer platform is quite a lot, among others: amartha.com, investree.id, koinworks.com, akseleran.com and artawana.com

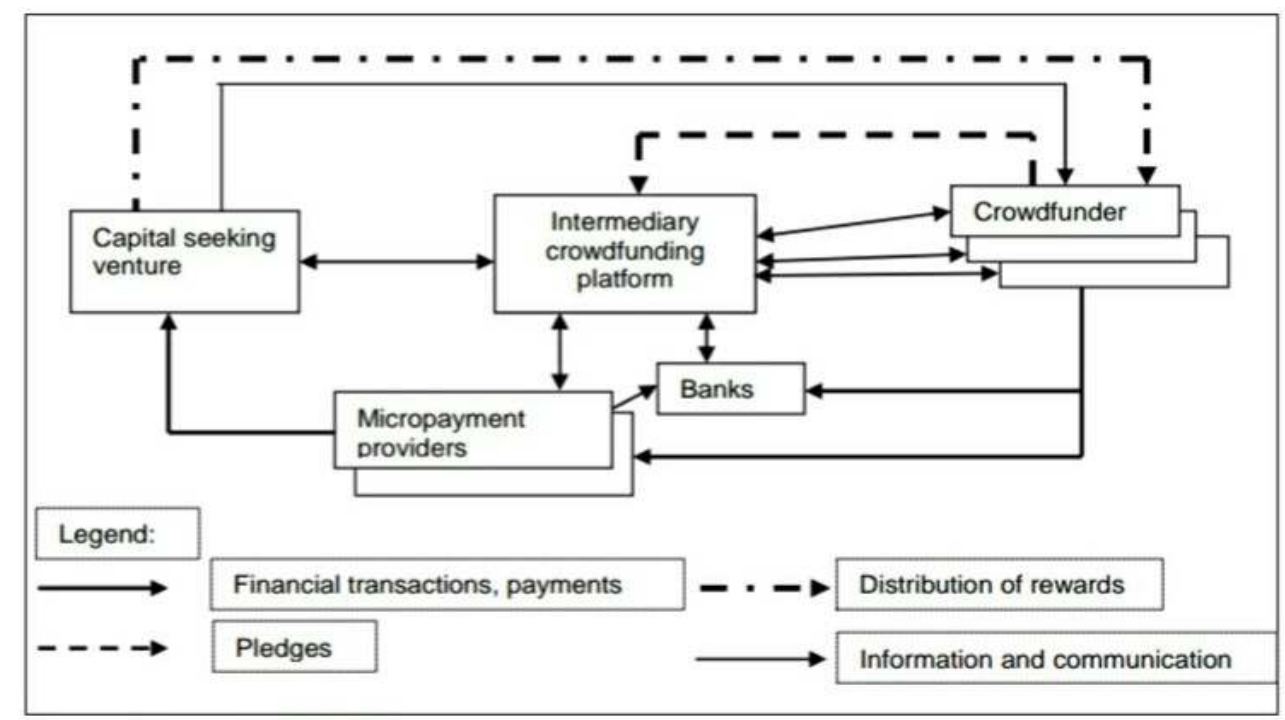

Figure 2. The Crowdfunding Process Involving Intermediaries [15] 
Financial limitations are felt in developing a business. Whether it is small and medium business. This working capital serves to finance all the operating costs of the company or to develop a good business to increase capital in providing raw materials or to buy a more modern production machinery. SMEs have to find capital loan to expand its business. Because the lack of capital will impact the business. Economic observers from the Institute of Economics and Finance (Indef) Imaduddin Abdullah revealed about 50\% of total micro, small and medium enterprises lack of capital [16]. To overcome the lack of capital, SMEs must get a loan. there are several sources of capital that can be utilized by SMEs, namely business capital derived from the government, business capital from banks, business capital from non-bank financial institutions such as cooperatives or from parties who provide loans in private or from moneylenders. Quite a few of the SMEs who took loans for venture capital came from moneylenders. The reason they took loans from loan sharks is that they do not require difficult requirements, the process is quick and can borrow in large numbers. Although they are aware of the risks that must be taken that is very high interest rates.

SMEs taking loans for venture capital come from moneylenders. Where it does not require a long and convoluted process. Simply come, give a guarantee and can bring the desired business capital. In contrast to if borrowed from a bank or non-bank financial institution.Apart from the banks, non-bank financial institutions and loan sharks. There is another part of the community that has a desire to help SMEs in While on the other part many people who want to participate to help SMEs in developing business. However, there are some concerns felt by the community if it helps this SMEs business, namely: (1) Difficulty to find info about the SMEs to be assisted; (2) Accuracy in the use of capital for business; (3) Accuracy in loan repayment; (4) Guarantees that can be given when borrowing; (5) The absence of financial statements making it difficult to monitor business progress.

To overcome these problems, it is necessary a container that can protect the community as an investor and SMEs as the recipient of funds for business capital. This container can be called crowdfunding. Where crowdfunding is more devoted to investment. Crowdfunding uses a peer to peer lending platform to facilitate between investors and SMEs. Peer to peer lending can replace the positions of banks, non-bank financial institutions and moneylenders as a fund for the SMEs. Platforms that can help connect between borrowers and lenders (investors) by utilizing the Internet can be called peer to peer (P2P) lending, where this platform can change transactions using conventional intermediaries [17]. Many benefits can be obtained from peer to peer lending platform compared with conventional lending transactions. Where the advantages of peer to peer lending are the borrower does not require a guarantee to get a loan as well as a short time to get a loan whereas from the side of the borrower or investor is obtaining a higher refund rate [18]. Crowdfunding is the same as the peer to peer lending platform has the function of helping people to find funding. Where this platform can help connect between those who have the funds with those in need without geographical restrictions [19].

There are several factors that cause investor not interested to invest to SMEs, that is: (1) Difficult to obtain information about the SMEs who need financial assistance; (2) The lack of trust to the SMEs whether the capital given, will be used properly; (3) There is a sense of worry if the given capital does not return; (4) SMEs has no business progress report; (5) Difficulty overseeing the provided SMEs financial assistance.Because of these factors. Finally, these investors do not want to help about the SMEs to provide capital.Expectations needed by investors so willing to help the capital to SMEs are: (1)Getting the data that SMEs really need; (2) Can help analyst SMEs who are eligible for capital assistance; (3) Provide oversight to SMEs so that SMEs actually use the capital properly; (4) There is a certainty that the capital 
will be returned; (5)Provide benefits to investors. From the desire of investors and supported by OJK, the peer to peer lending platform can be useful and attract the attention of investors.

The Government through OJK (Financial Services Authority) helps to provide security and comfort certainty both to investors and to recipients of funds, namely rule No. 77 / POJK.01 / 2016 on December 29, 2016 concerning Draft rules on lending and borrowing services based on information technology, which will regulate:(1) That the ownership of shares by foreign parties is a maximum of $85 \%$; (2) The company must have a minimum capital of 2.5 billion rupiah; (3) The existence of loan and interest limits is 2 billion rupiah, while the interest rate that can be given is 7x BI Rate; (4) The company must have an Escrow Account [20].

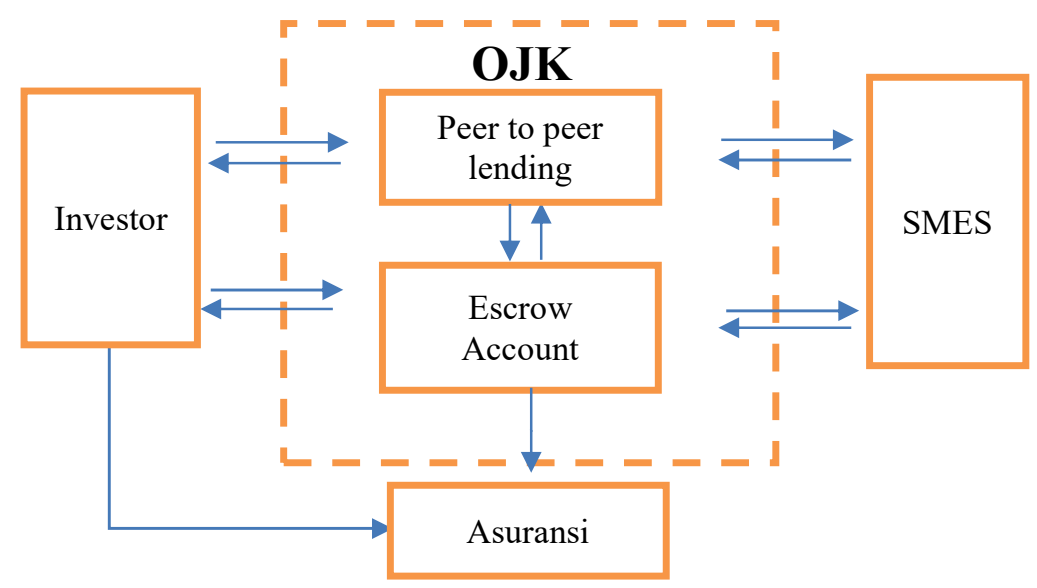

Figure 3. Peer to Peer Lending Platform Scheme.

\section{CONCLUSION}

The results of this study indicate that peer to peer lending has a good impact on prospective investors as capital providers and SMEs as recipients of capital. There are several things that affect potential investors so that being willing to become an investor is: (1) There is a guarantee from the government in this case the peer to peer lending platform under the supervision of the Financial Services Authority (OJK); (2)SMEs that can get funding assistance, have actually been selected and rigorously selected by peer to peer lending companies; (3) Transparent to the use of capital; (4) The amount of capital given is not large; (6). The borrowing period is not long; (7) Installments paid with the right time; (8) Profitable profit sharing; (9). Help develop SME businesses.

While the benefits for SMEs as recipients of funding are: (1) The loan process is not difficult; (2) There is no guarantee; (3) A relatively short payment time; (4) The number of installments is not large; (5) There is assistance for SMEs; (6) There is training as a provision for SMEs, such as branding, marketing and financial; (7) There are health services for SMEs; (8) Can get access if you want to get a large loan to the bank. From these results, the peer to peer lending platform can be used to attract potential investors, so that more and more SMEs in the region can be helped in business development.

With this peer to peer lending platform, it is hoped that investors can participate in developing SMEs. But investors must remain guaranteed, that: (1) SMEs can be trusted; (2) SMEs want to develop themselves to grow; (3) SMEs routinely make self-development reports, so investors can monitor the progress of the SMEs themselves; (4) Financial fund 
authorities as law enforcers must remain rigorous in overseeing companies that use peer to peer lending platforms, so as not to misuse investors' money for personal gain.

The limitations of this study are that samples from SMEs cannot be obtained maximally. Due to the very wide range of coverage of SMEs that have been financed by peer to peer lending platforms. Future research must be able to classify the types of businesses with each level and the population of the number of investors, both from novice, middle or high investors. The context of the benefits of peer to peer lending can be more targeted.

\section{Acknowledgement}

The authors would like to thank this research supported by Binus Entrepreneurship Center and colleagues who always provide support and thanks that are not counted to Indonesian SMEs.

\section{REFERENCES}

[1] D. Anggraini and S. H. Nasution, "Peranan Kredit Usaha Rakyat (KUR) bagi Pengembangan UMKMdi Kota Medan (Studi Kasus Bank BRI),” J. Ekon. dan Keuang., vol. 1, no. 3, 2013.

[2] H.-H. J. Li and K. H. Tan, "SMEs' business growth model: a medium to big effort," Int. J. Manag. Enterp. Dev., vol. 1, no. 3, p. 195, 2004.

[3] G. Ritchie, L. W. Komo, and I. K. Ngugi, "Key success factors of small businesses," Int. J. Bus. Glob., vol. 11, no. 1, p. 86, 2013.

[4] B. Hansen and R. T. Hamilton, "Factors distinguishing small firm growers and nongrowers," Int. Small Bus. J., vol. 29, no. 3, pp. 278-294, Jun. 2011.

[5] L. Van Scheers and S. Radipere, "Perceptions of small business owners on managerial skills: problems in business development in South Africa," World Rev. Sci. Technol. Sustain. Dev., vol. 2, no. 3/4, p. 336, 2005.

[6] A. Y. Jaelani, "Solusi Pinjaman Modal SMEs." .

[7] R. K. Yin, Case Study Research: Design and Method, 4th ed. London: Sage, 2009.

[8] G. Thomas, "How to Do Your Case Study: A Guide for Students and Researchers," Mod. Lang. J., vol. 97, no. 2, p. 231, 2011.

[9] J. Jauhari, "Upaya Pengembangan Usaha Kecil dan Menengah (SMES) dengan memanfaatkan e-commerce," J. Sist. Inf., vol. 2, no. 2, 2010.

[10] Rahardjo and Ali, "Faktor-faktor Keuangan yang Mempengaruhi Usaha Kecil dan Menengah di Indonesia Aspek-aspek Financial Usaha Kecil dan Menengah: Studi Kasus Aseaned James K and Akrasanee N,” LP3ES, Jakarta, 1993.

[11] A. Ordanini, L. Miceli, M. Pizzetti, and A. Parasuraman, "Crowd-funding: transforming customers into investors through innovative service platforms," J. Serv. Manag., vol. 22, no. 4, pp. 443-470, Aug. 2011.

[12] L. Attuel-Mendes, "Crowdfunding and Crowdmicrofinance, an Evolution of Models for Entrepreneurship of The Poor," Sci. Res., vol. 3, no. 12, 2016.

[13] Massolution, Crowdfunding Industry Report: Market Trends, Composition and Crowdfunding Platforms. Bloomberg: Crowdsourcing LLC, 2012.

[14] R. Soediro, "Perbedaan peer-to-peer lending dan crowdfunding," Investree, 2016. [Online]. Available: https://www.investree.id/blog/bisnis/perbedaan-peer-to-peerlending-dan-crowdfunding-70.

[15] J. Hemer, A Snapshot on Crowdfunding. Karlsruhe: Fraunhofer Institute for Systems 
and Innovation Research ISI, 2011.

[16] S. Festiani, "50\% UMKM Kekurangan Model," Antara News, 2015. [Online]. Available: https://www.antaranews.com/berita/486836/50-persen-umkm-kekuranganmodal.

[17] H. Yum, B. Lee, and M. Chae, "From the wisdom of crowds to my own judgment in microfinance through online peer-to-peer lending platforms," Electron. Commer. Res. Appl., vol. 11, no. 5, pp. 469-483, Sep. 2012.

[18] J. R. Magee, "Peer-to-Peer Lending in The United States: Surviving after Dodd-Frank," North Carolina Bank. Intitute, vol. 5, no. 1, 2011.

[19] A. Mateescu, "Peer-to-Peer Lending," Data Society, 2015. [Online]. Available: https://datasociety.net/output/peer-to-peer-lending/.

[20] A. H. Pratama, "4 Aturan OJK tentang Bisnis Peer to Peer Lending yang harus diketahui," Tech in Asia, 2017. [Online]. Available: https://id.techinasia.com/4-aturanojk-tentang-bisnis-peer-to-peer-lending-yang-harus-diketahui. 